\title{
THE APPLICATION OF IOT (INTERNET OF THINGS) FOR SMART HOUSING ENVIRONMENTS AND INTEGRATED ECOSYSTEMS
}

\author{
Andi Hildayanti ${ }^{*}$, M. Sya'Rani Machrizzandi ${ }^{2}$ \\ Department of Architecture, UIN Alauddin Makassar'1, \\ Department of Informatics Engineering, UIN Alauddin Makassar ${ }^{2}$ \\ e-mail: *1andi.hildayanti@uin-alauddin.ac.id, ${ }^{2}$ sya'rani.machrizzandi@uin-alauddin.ac.id
}

\begin{abstract}
Abstrak_Perkembangan teknologi meningkat pesat seiring berjalannya waktu. Mulai dari mobil pintar yang bisa berjalan sendiri ke berbagai tujuan tanpa pengemudi, hingga perangkat rumah pintar yang bisa secara otomatis bersuara mengingatkan untuk melakukan aktifitas sesuai jadwal. Semua teknologi terbaru ini adalah bagian dari Internet of Things. Internet of Things (IoT) adalah konsep dimana objek memiliki kemampuan untuk mentransfer data melalui jaringan tanpa memerlukan interaksi dari manusia ke manusia atau dari manusia ke komputer. IoT adalah struktur dimana, orang diberi identitas eksklusif dan kemampuan untuk memindahkan data melalui jaringan tanpa memerlukan dua arah antara manusia ke manusia, sumber ke tujuan atau interaksi antara manusia dan komputer. Jadi, penelitian ini bertujuan untuk mengidentifikasi dan menjelaskan penerapan sistem IoT dalam mendukung program smart building dan lingkungan yang terintegrasi. Penelitian ini dianalisis secara deskriptif kualitatif dengan pendekatan studi kasus untuk mengeksplorasi manfaat teknologi IoT. Hasil penelitian ini menunjukkan dengan menghubungkan sistem bangunan yang berbeda dengan sensor dan perangkat IoT yang terhubung ke jaringan, aplikasi bangunan pintar untuk lingkungan perumahan pintar, dan ekosistem dapat terintegrasi menggunakan data lintas operasi, memberikan visibilitas yang lebih besar, wawasan cepat, dan pengalaman penghuni yang lebih baik. Teknologi IoT dapat bekerja dengan baik jika interaksi antara perangkat IoT dengan manusia atau pengguna harus berjalan dengan baik, karena IoT tidak akan berfungsi secara optimal jika pengguna tidak dapat mengoperasikannya dengan baik.
\end{abstract}

Kata kunci: Internet of Things (IoT); Bangunan Pintar; Lingkungan Perumahan Pintar; Ekosistem Terpadu, Sistem Bangunan.

\begin{abstract}
Technological development increases rapidly over time. Starting from smart cars that can walk alone to various destinations without a human driver, to smart home devices that can automatically remind the voice to do activities on schedule. All of this latest technology is part of the Internet of Things. Internet of Things (IoT) is a concept where objects can transfer data through networks without requiring interaction from human to human or from human to computer. IoT is a structure in which objects, people are given an exclusive identity and the ability to move data through networks without requiring two directions between humans to humans, that is, sources to destinations or interactions between humans and computers. So, this research aims to identify and explain the application of the IoT system in support of smart building programs and integrated environments. This study was analyzed descriptively qualitative with a case study approach to explore the benefits of IoT technology. The results of this study indicate by connecting disparate building systems with networked IoT sensors and devices, smart building applications for smart housing environments and integrated ecosystems can use data across operations, providing greater visibility, valuable insights, and better occupant experiences. IoT technology can work well if the interaction between IoT devices with humans or users must go well because the function of IoT will not work optimally if the user cannot operate it properly.
\end{abstract}

Keywords: Internet of Things (IoT); Smart Building; Smart Housing Environment; Integrated Ecosystems, Building Systems.

\footnotetext{
${ }^{1}$ Department of Architecture, UIN Alauddin Makassar

${ }^{2}$ Department of Informatics Engineering, UIN Alauddin Makassar
} 


\section{INTRODUCTION}

The interaction between buildings and humans is very important to increase productivity, energy efficiency, and comfort in a building. For this reason, a number of technology companies are introducing smart buildings. The building sector is estimated to contribute 40 percent of world energy consumption. And predicted, in 2040 the total world energy consumption for buildings will increase by 80 percent (Fachrizal 2019). To answer this challenge, the concept of green and smart buildings continues to be carried out and encouraged by players in the building and property industry.

Buildings are an integral part of the urban ecosystem and now buildings are complex entities with several interconnected systems such as lighting, utilities, and security. Complexity increases with the size of the building and these buildings are susceptible to interference, which has the potential to cause loss of life and security of assets. Therefore, smart buildings have the potential to reduce the effects of disturbances and also enable proactive and intelligent actions to manage data to help them take preventative actions.

Smart building is when building system technology can automate and improve the performance of buildings and areas that apply the Green Building (Green Building) methodology in carrying out resource efficiency, resource conservation and efforts that make it possible to share resources. Smart buildings use an automated operational system, the Internet of Things (IoT) to control the process. This has an impact on design and construction, energy use, and how residents interact with space. To do this, the power of new technologies including mobile devices, cloudbased systems, artificial intelligence (AI), independent monitoring and collaboration platforms are used to make fundamental improvements in building performance.

IoT has grown rapidly from the incorporation of wireless technology, MicroElectromechanical Systems (MEMS) and the Internet. IoT uses a number of technologies that are widely combined into one unit including sensors as data readers, internet connections with various types of network topologies, Radio Frequency Identification (RFID), wireless sensor networks and technologies that will continue to grow as needed (Wang et al. 2013). IoT can also include other sensor technologies, such as wireless technology and QR codes that we often find around us, examples of their applications in real-world objects are for food processing, electronics, and various other machines or technologies that are all connected to the local network and automatically globally through embedded sensors and always active. This IoT refers to a mahcine or device that can be identified as a virtual representation in its Internet-based structure. Such as gesture, facial expression (Lawi and M 2018), etc.

Like the work of WISER wireless smart home systems, this is a solution that is able to provide real-time data that enables home and building owners to be able to have control over their homes becoming greener and more efficient. Examples of such controls are environmental adjustments, lighting controls, energy efficiency management, personal safety, home security. Interestingly, this control can be done only through a mobile application and even from very long distances though because this solution depends on the internet network.

This IoT technology has begun to be developed by many companies in Indonesia as a step forward and evidence of the development of global technology has penetrated into Indonesia. one of them is SoftwareSeni Indonesia. In addition to creating digital products (websites, SoftwareSeni (2019), and mobile applications), SoftwareSeni also develops IoT. Through the SSLab team led by Heryno Cheung, the development of IoT by SoftwareSeni is indeed not at a stage that can be mass- 
produced and used by the community. in addition, there is also Qlue which is a startup company that is famous for the Smart City project and also develops IoT. Some of the developments in IoT made by Qlue are:

(1) Development of Traffic Lights connected to the Command Center.

(2) Smart trash box

(3) Air Pollution Detector

And of course, the development of IoT products is to support Smart City projects in major cities in Indonesia.

So, in this study aims to explain that Internet of Things is a solid technology foundation for smart buildings with the growing number of smart building devices, applications, and solution providers, choosing the right technology foundation is critical. Leading equipments and systems integrators rely on IoT Technology to deliver smart building solutions that are secure, scalable, and interoperable.

\section{METHOD}

This study is a qualitative research, which used to examine the condition of natural objects, where researchers are key instruments. According to Saryono (2010), qualitative research is research that is used to find, discover, consider, and explain the quality or features of social interaction. Data collecting in qualitative research are the data comes from a number of case study examples that are described descriptively and are supported by illustrations and photographs to reinforce the arguments put forward. So in this research using case study method for exploring the findings. Case study is a form of qualitative research that focused on providing a detailed account of one or more cases.

The case study selection process is based on several sources such as YouTube, the company's website offering IoT services, workshops resume, and seminars that discuss about the role of IoT in the city improvement. The case study selection criteria are homes that have implemented the IoT system as a building support device. It aims to show the privilege of implementing the IoT system itself.

The case study research method examines specific cases or phenomena that exist in a society that are carried out in-depth to study the background, circumstances, and interactions that occur. Case studies are carried out on integrated systems which can be programs, activities, events, or groups of individuals that exist in certain circumstances or conditions. In this research, data collected are literature and examples of IoT (Internet of Things) implementation at home in some cases (case studies) in their homes, housing environment and ecosystem integration. Some research focuses include building components including home furnishings, sensors, IoT (Internet of Things) work mechanisms, features, and IoT benefits in realizing smart homes.

\section{RESULT AND DISCUSSION}

Smart Home and smart building, it is a system that collects and makes sense of thousands of sensors generating data all over the house or building. These sensors collect all kinds of information things like energy usage, space utilization, occupant productivity providing better insight and control over a board range of systems that span the entire building but it's not sensors 
that make a building smart. It is the ability to process and learn from all the data those sensors provide take a typical day that building.

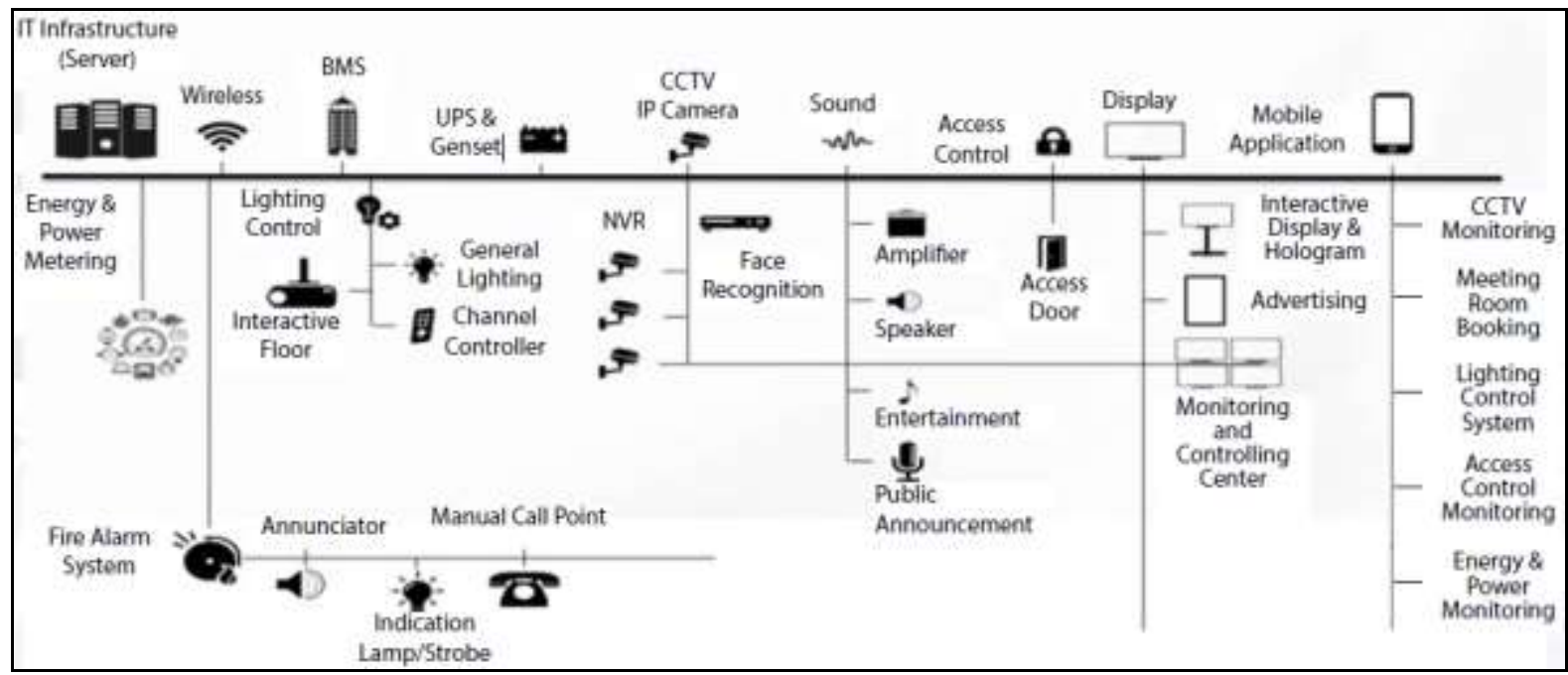

Figure 1. Mechanism of IoT technology in the building Source: IoT Catalog, 2019

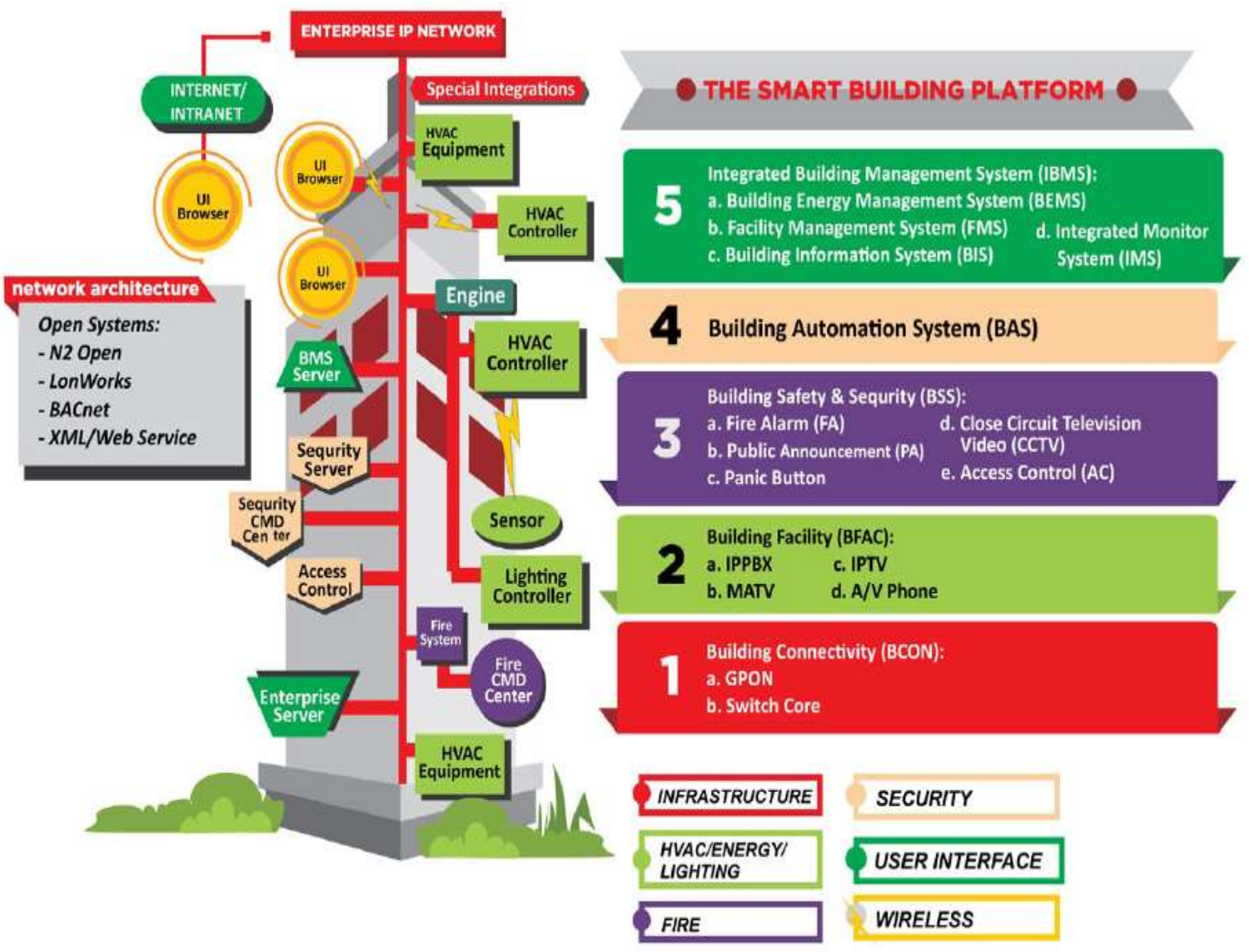

Figure 2. Mechanism of IoT Technology in the Building Source: IoT Catalog (2020) 
The occupants can monitor the entire building everything and can see what areas are drawing the most energy throughout the day and suggest the ways to remedy inefficiencies reducing utility costs. The occupants also know which areas of the building are more frequently used and can plan an optimized space utilization and maintenance based on work schedules which is great considering 39\% of worker prefer a flexible workspace and don't necessarily need a desk every day.

A truly smart home contain ability to analyze the environment and make real-time adjustments to improve efficiency and productivity. Smart home and smart building supporting 50 billion connected devices with cloud-based software and services growing at a rate of $33 \%$ an Internet of Things enabled environment helps to simplify the tasks of managing risk improving network performance enhancing workforce productivity and better space utilization. The five senses that enable intelligent building include environmental monitoring, visual management, communication enablement, security integration, and network connectivity.

To get Internet of Things enabled in the house or building it is critical to maintain a network infrastructure that can support Ethernet based connectivity platform migrating legacy edge devices onto the network may be initially achieved through media conversion and protocol adapters however ultimately connecting the Internet of Things on a scalable and standards compliant structured cabling system in essential for the interoperability of the network.

The implementation of IoT technology in smart home design can be seen in the figures below.
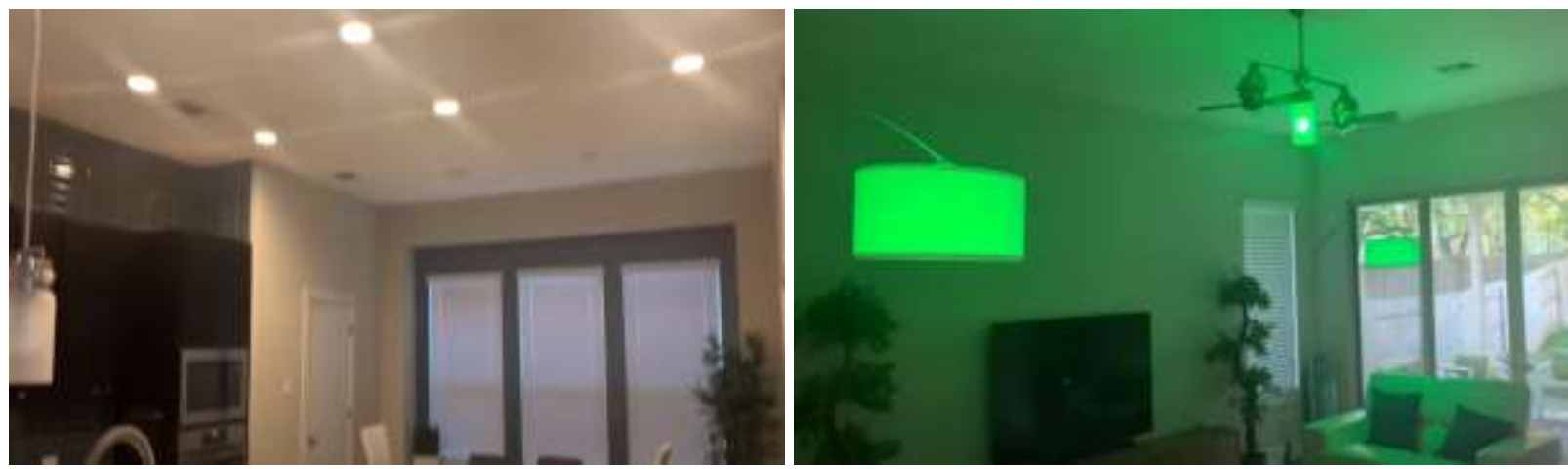

Figure 2. Lighting Control from IoT Technology Implemented in Austinite's Home \& Lawn Source: Lawn (2019) "Smart Home Tour"

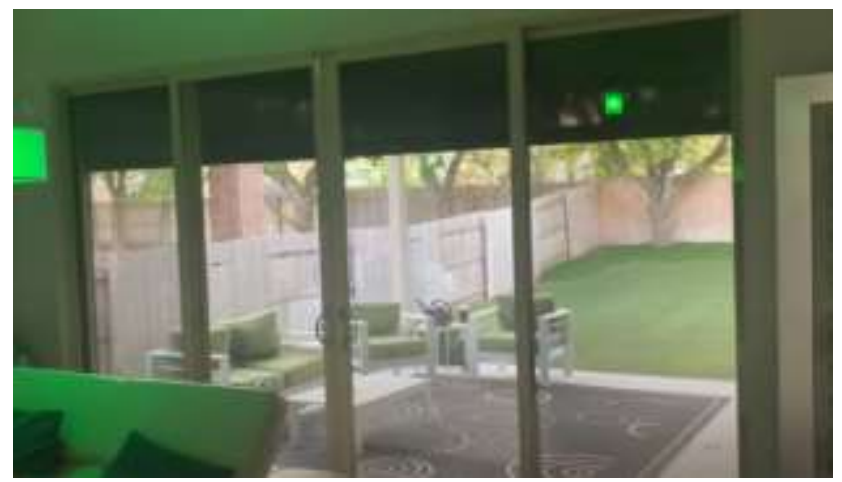

Figure 3. The curtain control from IoT technology implemented in Austinite's Home \& Lawn Source: Lawn (2019) "Smart Home Tour" 

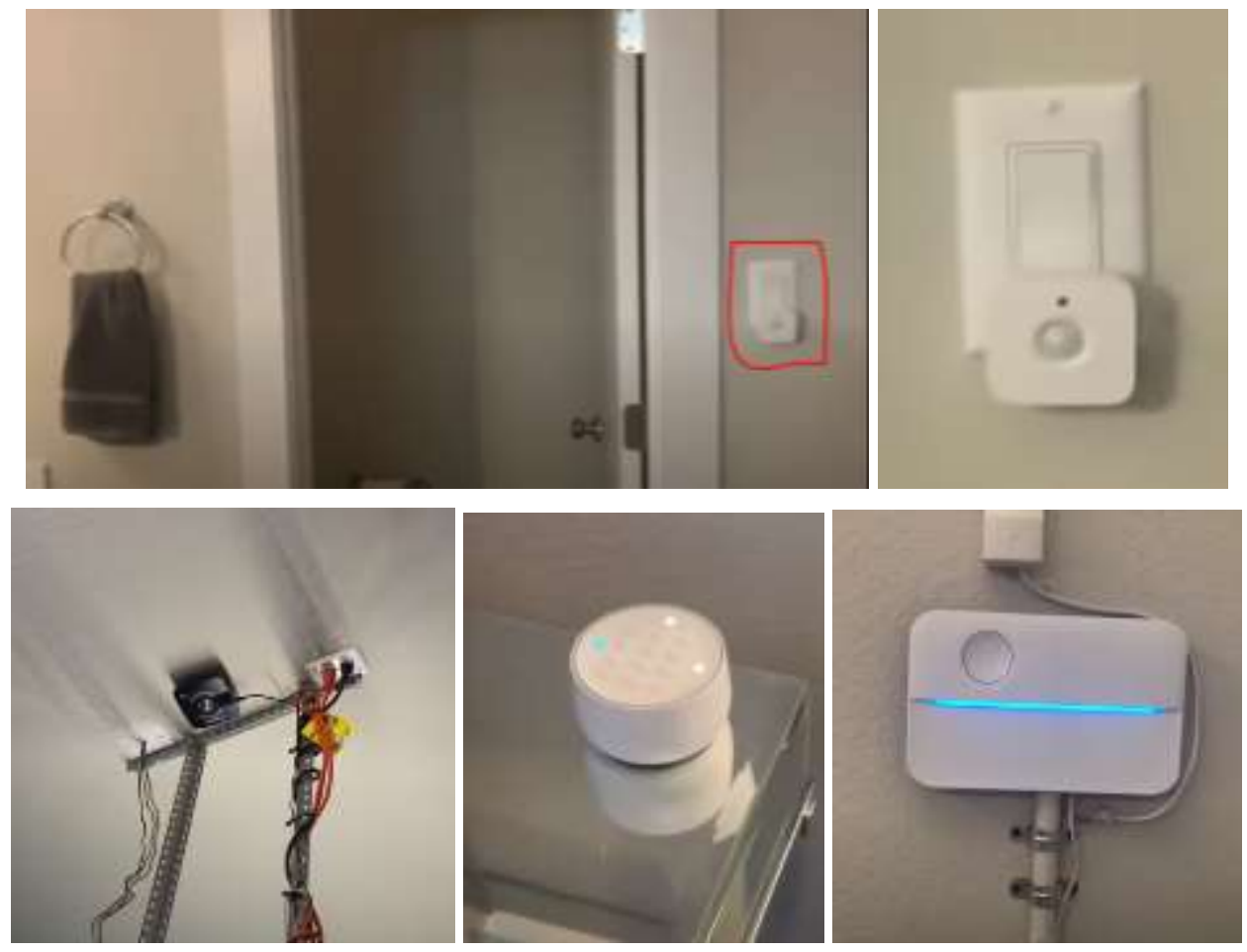

Figure 4. Sensor Location Installed Source: Lawn (2019) "Smart Home Tour"
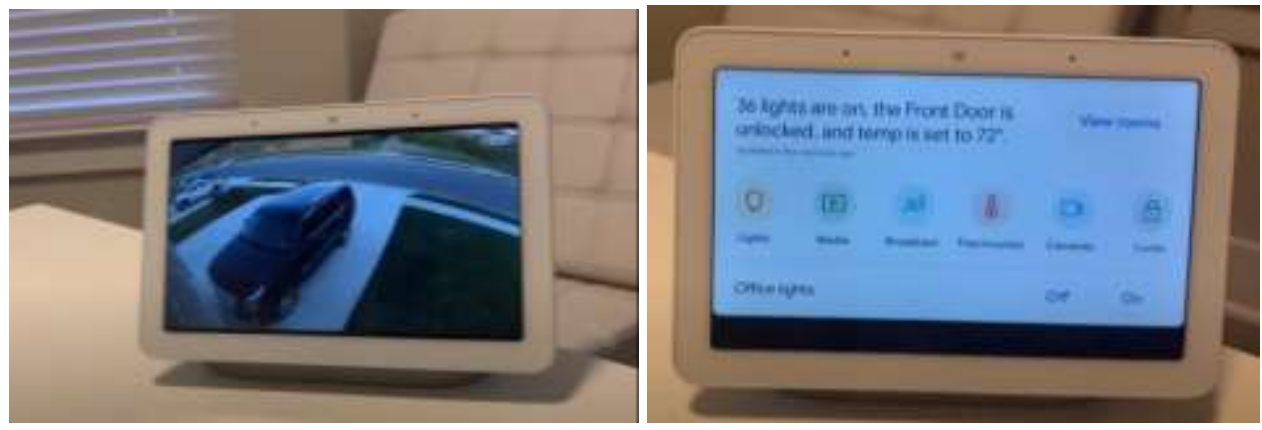

Figure 5. Monitoring Process Via Gadget Source: Lawn (2019) "Smart Home Tour"

The best way to benefit from an integrated Internet of Things environment in the building choosing the right technologies along with adopting best practice for installation include implementing an open architecture approach, using interoperable hardware, understanding IT strategy.

Smart Home is a service solution for controlling various devices such as TVs, air conditioners, lights, curtains, and security sensors such as IP CCTV, smoke detectors, LPG detectors, and other devices through applications so that users can monitor and adjust schedules, use timers and interactions between sensors/devices in real-time. IoT technology features contained in smart home include:

a) Home Monitoring, to display various devices that have been integrated with Smart Home Gateway.

b) Device Management, to group sensors/devices and its categories. 
c) Building Connectivity (BCON), which consists of GPON (Gigabit Passive Optical Network) and Switch Core.

d) Building Facilities (BFAC), consisting of IP PBX (Private Branch Exchange), IPTV, and AV Phone.

e) Building Automation System (BAS), a system that monitors, controls, and maintains mechanical and electrical equipment in buildings automatically and in real-time.

f) Integrated Building Management System (IBMS), consisting of Building Energy Management Systems (BEMS), Facility Management Systems (FMS), Building Information Systems (BIS), and Integrated Monitoring Systems (IMS).

g) Safety and Security Building (BSS), which consists of a Fire Alarm, Public Announcement System, CCTV (Closed Circuit Television), Access Control and Panic Button.

While the benefits are obtained by implementing IoT technology at home are :

a) Security is integrated and can notify owners and security parties with the approval of an abnormal representative.

b) Can set several sensors that have been determined.

c) Easy to use a smartphone, which can be accessed anywhere and anytime

d) Lower electrical energy consumption.

e) Automation of management makes the management costs become more efficient.

f) Increase comfort and safety.

g) Can be integrated with various devices.

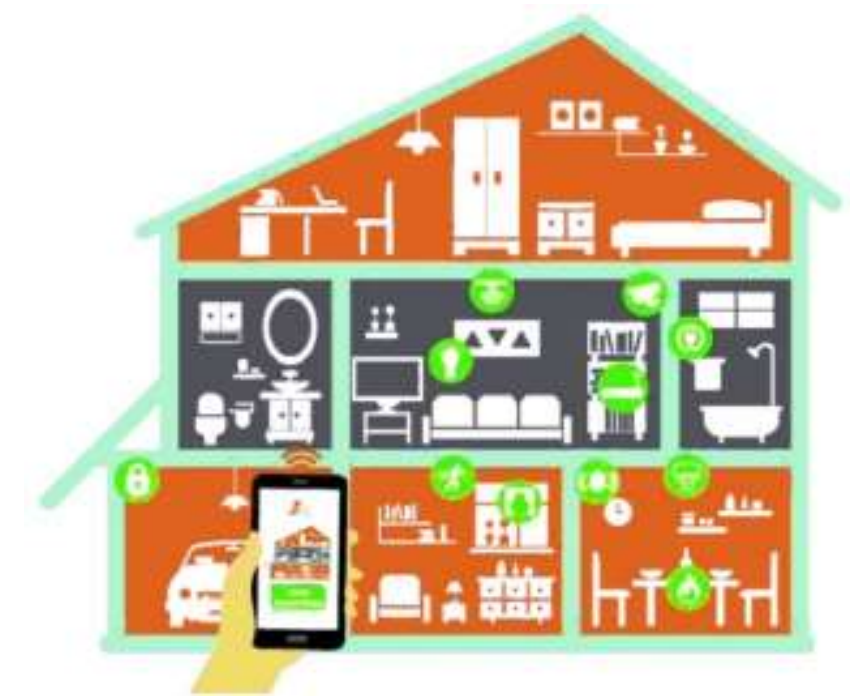

Figure 6. The application of IoT technology for Smart Home

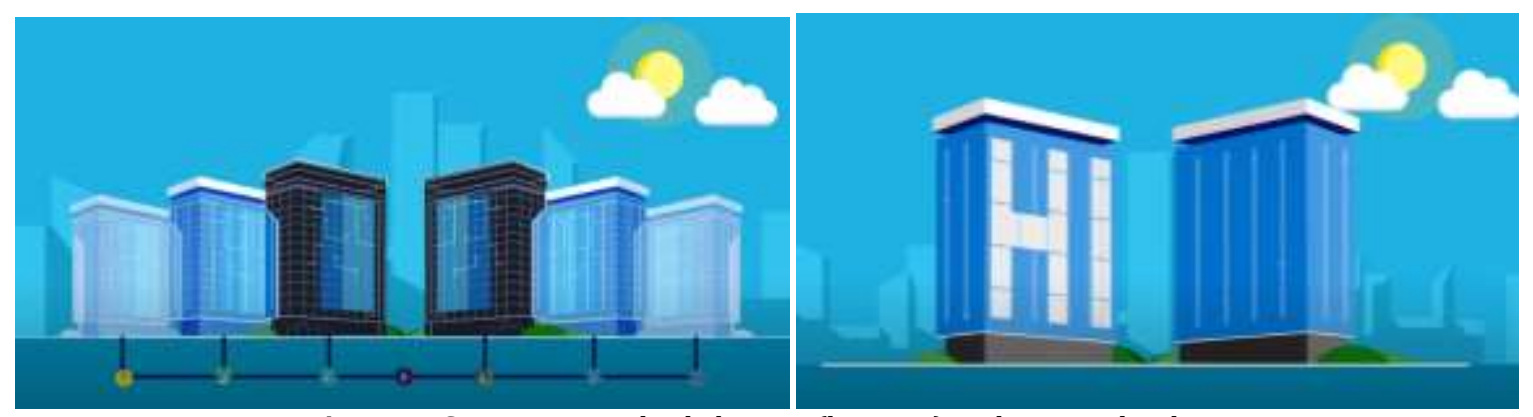

Figure 7. Connecting multiple houses (housing) with IoT technology Source: "Microsoft IoT for Smart Buildings" (Friedman 2016) 
Based on figure 7, IoT technology can connect multiple houses and pull everything together into one system creating new efficiencies across their entire housing. So, house can be connected just like some say hello to the other house can discover IoT technologies are creating smart home.

In terms of energy, a number of devices that consume large amounts of energy now can be integrated with internet connectivity that allows machines and networks to communicate in balancing power plants and using energy more efficiently and effectively. This device can also allow remote control access from users. In addition, it can also activate functions such as scheduling (for example to turn on / off the heating machine, control the oven, change the lighting conditions from bright to dim to dark, etc.).

Whereas from an environmental aspect, the environmental monitoring application from IoT usually uses sensors to help realize environmental protection. Examples of applications include monitoring air or water quality, atmospheric or soil conditions, and can include monitoring wildlife and their habitats. IoT is also used in disaster management such as Tsunami Early Warning or earthquake systems. IoT devices, in this case, have a very broad geographic range and can move.

In Home Automation aspect, IoT devices are used to monitor and control mechanical and electronic systems used in various types of buildings, such as industry or housing. It can also control energy usage in real-time in reducing energy consumption. IoT devices can be integrated into smart home systems. Examples of applications such as lights automatically turn on at night, then the lights will automatically turn off during the sleep schedule. In the morning, your garden will be doused with water by an automatic sprinkler machine. Likewise with your refrigerator that can order your own food stock when it runs out.

Based on the results of applying the IoT system in the case studies that have been explained it is known that basically all types of homes can implement the IoT system as a supporting device to improve the comfort and safety aspects of their homes. In addition, for a good implementation, this IoT needs to have good integration between humans, technology, and the environment. The operating process of IoT system both at the micro-scale (home) and macro-scale (housing) has almost the same principles and mechanism of work, only the scale of infrastructure that differentiates depends on the number of users. For IoT technology work properly, interactions between IoT devices and humans or users must work well. The function of IoT will not work optimally if the user cannot operate it properly.

Humans as users have the role to make decisions must be able to read the information that has been processed by the IoT device. If the user cannot read the information properly, it is possible that the decision made will be contrary to the expected results. Therefore, preparing human resources for digital literacy has become a necessity. If you cannot adapt to technology, then don't expect the development and implementation of IoT to work properly.

\section{CONCLUSION}

IoT technology has been widely applied in several countries and it is considered effective in realizing smart building programs and smart housings. The advantages of applying this IoT technology make it easier for occupants to monitor and control the mechanism of existing buildings and furnishings, environmentally friendly makes low energy consumption in buildings and ecosystems, management automation makes management costs more efficient, and improving the comfort and safety of residents. Smart Building is a great solution for building automation services 
and infrastructure that applies smart, energy-efficient (green building) building arrangements, automation systems and Advance HVAC (Heating Ventilation and Air Conditioning). However, this IoT technology must be supported by the strength of a capable internet network so that the application of IoT technology in buildings can run efficiently and effectively.

Therefore, Indonesia must prepare regulations that can facilitate the process of developing and implementing IoT technology. Without regulations, developers do not have a strong legal basis for developing and implementing IoT technology that is safe for the community. The word "safe" here means reliable and durable. When the government has clear rules regarding the standardization of IoT technology, developers will easily adjust IoT devices to follow established rules.

\section{REFERENCE}

Fachrizal, Rafki. 2019. "The Important Role of Technology in Supporting the Existence of Smart Buildings." The latest news page Infokomputer. 2019. https://infokomputer.grid.id/read/121665861/peran-pentingteknologi-dalam-mendukung-hadirnya-bangunan-pintar?page=all.

Friedman, Felix. 2016. "Microsoft IoT for Smart Buildings." YouTube video. 2016. https://www.youtube.com/watch?v=CEAyzkuuAQ8\&feature=youtu.be .

Indonesia, Telkom. 2020. "M2M (Machine to Machine) / IoT (Internet of Things)... Enterprise Service Division." Indonesia: Telkom Catalog. PT Telkom Indonesia Tbk.

Lawi, Armin, dan Sya'Rani Machrizzandi M. 2018. "Facial Expression Recognition using Multiclass Ensemble LeastSquare Support Vector Machine." IOP Conf. Series: Journal of Physics: Conf Series 979. https://doi.org/10.1088/1742-6596/979/1/012032.

Lawn, Austinite's Home. 2019. Smart Home Tour. YouTube video. https://www.youtube.com/watch?v=q-X0CHEe-I.

Saryono. 2010. Qualitative Research Methods (Metode Penelitian Kualitatif). Bandung: PT. Alfabeta.

SoftwareSeni. 2019. "Ready to welcome the Internet of Things (IoT), Indonesia?" BUSINESS. DEV, TECH.

Wang, C, M Daneshmand, M Dohler, X Mao, R. Q Hu, dan H Wang. 2013. "Guest Editorial - Special Issue on Internet of Things (IoT): Architecture, Protocols and Services." IEEE Sensors Journal 13 (10): 3505-3508. https://doi.org/10.1109/JSEN.2013.2274906. 